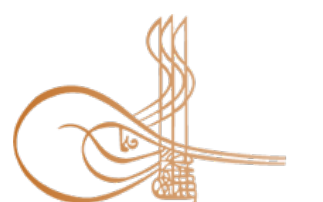

www.turkishstudies.net/social
Turkish Studies - Social Sciences

eISSN: 2667-5617

Research Article / Araștırma Makalesi

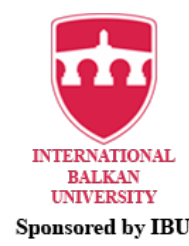

Sponsored by IBU

\title{
19. Yüzyıl Balkan Milliyetçiliğine Bir Örnek: Bulgaristan'ın Tarihsel Makedonya Hayali
}

\author{
An Instance of 19th Century Balkan Nationalism: Historical Macedonia Dream of Bulgaria
}

\author{
Gülten Haliloğlu*
}

\begin{abstract}
Symbols, myths, legends and traditions which came from the past have a special importance. These images are elements that states don't want to share among themselves. Having these elements, attributing them to your own history or having a special image which enables one to make a reference to the past pave the way for the states to legitimize their upcoming plans. No doubt, the territorial integrity is really significant for every state. The territorial existence is as significant as the existence of both ethnic and other identities for the states to express themselves. When the historical process is considered, it is seen that Balkan people who fell under the Ottoman Empire for a period is successfully administered with the 'Millet System' the state put into practice. The millet system categorizes the peoples not in regard to ethnicity but in regard to the religion which they belong to. However, the millet system began to weaken due to the influence of both the movement of modern nationalism and some other elements. In Balkan nationalism, which emerges for this reason is both seen that the Balkan peoples acted on the basis of the ideal of redomination the places that they claim they have and embraced an irredentist policy. Therefore, for Bulgaria, Macedonia firstly means to integrate with their own ethnic identity and their own natural boundary. For Bulgaria, Macedonia is in the position of an ideal which always exist in their historical past and is a natural spite of their territory. To achieve this ideal, Bulgaria wanted to make use of the current position of the 19th century Balkans and tried to direct their policy on the basis of the ideal of repossessing Macedonia.
\end{abstract}

Structured Abstract: The Balkans have been a strategic region for many states throughout history. It is not enough to just rule the Balkans where every state has an absolute valid reason in order to rule. Also, a state authority which will maintain this domination consistently is required. Ottoman Empire which has a broad land area from Middle East to the Balkans has created a powerful administration and an organization for the regions and the people under its domination which depends on the rules that Islamic religion requires. Ottoman Empire has developed a system which takes shape according to the religious identity of its subject. This system shaped according to the religion and called "Millet System" that so to say, is an ideal legal, economic and social community organization which unites the Balkans under a single roof. The Balkans where many different languages, ethnic groups and religious affiliation are, has been ruled for centuries successfully thanks to this system.

However, as a result of the appearance of the nationalism movement in time and affecting over the peoples by gaining power, the communities in the Balkans have been in search of remembering their nonreligious identities (national identities). Primary purpose of these communities has been to built their identities

\footnotetext{
* Doktora Öğrencisi, Trakya Üniversitesi, Sosyal Bilimler Enstitüsü, Balkan Çalışmaları PhD. Student, Trakya University, Institute of Social Sciences, Balkan Studies 
by remembering their past. Transferring these new identities they have built to posterity and in this way establishing a national state has become a primary target for them. Actually, nationalist ideas and individuals who have this kind of ideas (poets and clergymen) have existed before the nationalism movement. This situation has provided a basis for arising of nationalism and the ideas of independence. The people in the Balkans have used teachers and clergymen as a tool in order to spread their national values by consisting a solid ground for the nationalism by the way of education and religion. Thus, religious identities have influenced national identities by growing and developing. As a result of all of these efforts, they have started the process of becoming nation-state. The reasons such as rising of the nationalism when Millet System which Ottoman Empire applies starts to weaken has increased the demand of independence of the people in the Balkans. After the demands of independence, new states have been established but these nation-states established have not been pleased about their boundaries in no way. It is seen that these states consistently want to change their boundaries. It is known that Bulgarians who is one of them has some historical claims on Macedonia.

In this study, it is mentioned that putting in a claim for a region in the context of nationalism is directly proportionate with trying to testify that they are in that region since antiquity. Because, the past is a significant reference source for the future. While the future is built, the past is benefited. For this reason, especially when the people in the Balkans want to establish a nation-state, when they have a disagreement about the boundaries, they have tried to testify their rightfulness by always referring to their states in Medieval Age. In this way, they are in an effort for providing a right and a legit basis. Bulgarians as one of the people in the effort for providing a legit basis in the Balkans, attach to their past rigidly due to these reasons. Bulgarians have usually tried to keep alive the idea of re-dominating the broad boundaries which they had in Medieval Age and have directed their policy in this way. This policy has created the ideal of the Big Bulgaria. Thus, Bulgarians have felt the need of testifying that they had been in that region since Medieval Age. According to Bulgarian nationalists, idealized state and the boundaries that the state has, were the boundaries of Medieval Empire of Boris I who has the title of "the tzar and the absolute ruler of all the Bulgarians and the Greeks". These boundaries involved Macedonia because the major axis of the policy of being The Big Bulgaria was to have Macedonia. Macedonia region which speaks a Slav-origined language and has an Orthodox population was very significant because it has a similarity with Bulgarians' national elements. For this reason, Bulgarian nationalists had shown a great effort for the separation of Bulgarian and Greek churchs. They have focused on making propagandas and setting organizations in order to have Macedonia and for the propaganda they have used teachers and clergymen as a tool. In this period, it is known that some clergymen such as Paisii, Sofroni and Neophtos have a huge effect on that Bulgarians have both nationalism and the idea of independence.

Ottoman-Russian War in 1877-1878 was a turning point for the ideals of Bulgarians because with the treaty of San Stefano signed in the end of this war Bulgarians had reached the boundaries of Medieval Bulgaria they dreamt. However, even though they reached the boundaries they aimed, as a result of giving a negative response of other states to this situation, Bulgarians have got again disappointed and they have lost the domination fields they have reached with the treaty of Berlin before. When looked at the next periods chronologically and when it is considered that Bulgaria has engaged with the wars of Balkan War I, Balkan War II, World War I and even World War II successively, it can be seen clearly that they have always kept their dreams alive for their aims on Macedonia. In order to make real this dream or aim, Bulgaria has tried to have Macedonia through sometimes Orthodoxy, sometimes ethnic belonging and sometimes language. Other states in the Balkans have asserted various claims on Balkan boundaries just like Bulgarians. Although these new nation-states in the making built their existence on their past history and myths, it is seen that these myths, common ethnicity and common religion do not strengthten the relationship among them, on the contrary they do drag them to the conflict. For instance, although the people of Serbian, Greek, Bulgarian and Romanian have the same religious identity that is to say Orthodox identity, they cannot come together. Hence, every state, every ethnicity, every identity and every nationalism has particular aims and policies which they want to make real. One of the instances that can be given for this situation is that the result of the Balkan War I caused the Balkan War II.

Keywords: Nation, Nationalism, Nationalism of Balkan, Bulgaria, Macedonia.

Öz: Geçmişten gelen semboller, mitler, efsaneler ve gelenekler özel bir öneme sahiptir. Bu imgeler devletlerin aralarında paylaşmak istemediği unsurlardır. Bu unsurlara sahip olmak, bunları kendi geçmişine atfetmek ya da geçmişe referans yapacağı özel bir imgeye sahip olmak, bir devletin günümüzde atacağı adımlara meşruiyet

Turkish Studies - Social, 15(4) 
kazandırmasına zemin hazırlamaktadır. Her devlet için kuşkusuz topraklarının bütünlüğü önemlidir. Ulusların kendini ifade etmesinde ve ulusçuluğun-milliyetçiliğin kendini anlamlandırmasında, etnik ve diğer kimliklerin varlığı kadar toprakların varlığı da önemlidir. Tarihsel sürece bakıldığında bir dönem Osmanlı Devleti'nin çatısı altında bulunan Balkanlardaki halkların, devletin uygulamaya koyduğu 'Millet Sistemi' ile başarılı şekilde yönetildiği görülmektedir. Millet sistemi halkları etnisiteye göre değil mensup bulundukları dine göre gruplandırmıştır. Ancak modern milliyetçilik akımı ve birtakım başka unsurların etkisiyle 'Millet Sistemi' zayıflamaya başlamıştır. Bu yüzden ortaya çıkan Balkan milliyetçiliğinde ise Balkan halklarının eski tarihlerde sahip olduğunu iddia ettikleri yerlere yeniden hükmetme düşüncesini baz alarak hareket ettikleri ve irredantist bir politika takip ettikleri görülmektedir. Bu nedenle Bulgaristan açısından Makedonya, öncelikle kendi etnik kimlikleriyle ve kendi topraklarının doğal sınırlarıyla bütünleşme anlamına gelmektedir. Makedonya, Bulgaristan için tarihsel geçmişlerinde her daim var olan ve topraklarının doğal uzantısı olan bir ülkü, bir ideal konumundadır. Bulgaristan bu ideale erişebilmek için 19. yüzyıldaki Balkanların mevcut durumundan faydalanmak istemiş ve politikasını Makedonya'ya yeniden sahip olma amacını taşıyarak yönlendirmeye çalışmıştır.

Anahtar Kelimeler: Millet, Milliyetçilik, Balkan Milliyetçiliği, Bulgaristan, Makedonya

\section{Giriş}

"Millet-ulus" kelimesi 13. yüzyıldan beri kullanılmakta olup "nasci” doğum manasına gelen Latince kökenli bir kelimeden türetilmiştir. Kendine özgü anlamıyla millet, hiçbir siyasi atıf taşımaz, fakat bununla birlikte rrksal bir gruba işaret etmektedir (Heywood, 2011: 167). Milletlerin kendilerine ait miraslarını oluşturan, değer, sembol, gelenek-görenek, mitlerinin süreklilik göstermesi ve bireylerin kendilerini bu özelliklerle birlikte tanımlamaları ulusal kimliklerin özünü oluşturmaktadır (Smith, 2000: 796). Ernest Renan'a göre ulus-millet 'müşterek zengin bir hatıralar mirası' ve 'birlikte yaşama rızası' dır. Herşeyden önce manevi bir ruh hâlidir ve geleneksel bir yapısı vardır (Renan, 1946: 120). Gerd Baumann'a göre, “üyelerinin bir devlete sahip olduğunu düşünen ya da bir şekilde düşündürten yani buna karşı özel bir sorumluluk taşıyan bir ya da birden fazla etnik gruptur" (Bauman, 2006: 36). Anthony D. Smith'e göre ise mitleri, kültürü, tarihi, ülkeyi, yasaları ve ekonomiyi 'ortak' olarak paylaşan kitle'dir (Smith,1994: 31). Milleti açıklamaya çalışan farklı parametrelerdeki yaklaşımların, teorilerin ortak noktası, modern manada ulusun-milletin politik ve kültürel bir boyuta sahip olmasıdır. Buna göre millet-ulus, ulus-devlet modelinde hem homojen kültüre sahip toplumu hem de egemenliğin kaynağını gösteren siyasi-politik düzeyde yer almaktadır (Şener, 2014: 57).

Modern milliyetçiliğin kurucusu Jean-Jacques Rousseau'ya göre ulusun tek bir hükümdarın öncülüğünde olması reddedilmeli, ulus ve halkı özdeş sayılmalıdır (Carr, 1993: 20). Bu haliyle milliyetçilik, insanlığın ulus-devlet yapısı içinde organize olmasını gerektiren doktrindir (Kedourie, 1970: 29). Milliyetçilik kendi etnisitesindeki halklara seslenip onları bir arada tutmak ve birlikteliği güçlendirmek adına propaganda, tarihi birliktelik, ortak düşman, seferberlik gibi unsurlara atıf yapmaktadır. Örneğin, milliyetçilik seferberlik çağrısında bulunurken tehdit algısı olduğundan hareket ederek ideolojik düşman yaratır. Böylece tehdit alan ve zarara uğramış ya da uğrayacak olan etnisiteyi bir araya getirerek kendini kanttlama ihtiyacı olduğunu ileri sürer (Delannoi, 1998: 33). Benedict Anderson, milliyetçiliğin, 'liberalizm', 'faşizm' haricindeki 'akrabalık' ve 'din' gibi unsurlarla da alakalı olduğunu (Anderson, 2009: 20) ve bu şekilde daha kolay anlaşılabileceğini ifade etmektedir. Din ve milliyetçiliğin arasındaki ilişki birçok yönden karmaşıktır. Özellikle geleneksel dönemde temel prensipleri gereği din, inanan kişilerin etnisite, dil ya da teritoryal yönüne ayrım yapmadan yaklaşmaktadır. Bu nedenle Hristiyanlık, Müslümanlık ve Budizm gibi dinler belirli bir etnik grup içerisinde ortaya çıktıktan sonra, misyonları gereği evrenselleşir (Sadoğlu, 2016: 3). Belli bir sınıfa seslenmek için var olduğu düşünülen dinler bile sadece özel bir sınıfa seslenmekle yetinmez. Örneğin 5.yüzyıl İran'ındaki Mazdekçilik, alt sınıfa seslenmekteyken 18.yüzyıl İngiltere'sindeki Anglikanizm, orta ve üst sınıfa seslenmektedir. Ancak gerçekte her iki dinin de amacı evrensel olabilmektir (Smith, 1994: 20). Dinin ve diğer pek çok etkenin dışında milliyetçilikte 
siyasal katılım da oldukça önemli bir yapıya sahiptir. Nitekim 17. yüzyılda İngiltere'de, 18.yüzyıl'da ABD ve Fransa'da, 19. yüzyıl'da ise Almanya'daki toplumların siyasal katılımlarının artması, milliyetçiliğin tam manasıyla meydana gelmesine katkıda bulunmuştur (Delannoi: 34). Kısaca özetlemek gerekirse milliyetçilik ve onu oluşturan her türlü algının (tarih, din, etnisite, siyasal katılım vb.) halkları siyasi, sosyal ve kültürel olarak harekete geçirmeye muktedir canlı bir yapısı olduğu gözlemlenmektedir.

\section{Osmanlı Devleti’nin Milliyetçiliğe Bakışı: Millet Sistemi}

İslamiyet, sınıf ayırt etmeksizin ve etnisiteye bakmaksızın tüm insanlığa ve dahası tüm evrene gönderildiğini ilan etmiş bir dindir. Osmanlı Devleti'nin temel referans kaynağı İslam olduğu için devletin yönetim ve organizasyonu İslamiyet'in gerektirdiği temel kurallar üzerine oluşturulmuştur. Osmanlı Devleti'nde, Ehl-i Kitap (ilahi bir kitaba inananlar) olan gayrimüslimlere, İslam devletinin çatısı altında olmayı istedikleri zaman "Allah ve Peygamberi zimme"si verilir ve bu şahıslara "zımmi" denilmiştir. "Zimme" kelimesi ise tam manasıyla himaye etme, koruma anlamına gelmektedir (Küçük, 1999: 210). İslam hukukunda, İslam devletinin himayesini kabul edenlerin can ve malları güvence altına alınarak kendi dinlerini ve ibadetlerini özgürce yaşamalarına izin verilmektedir (Özcoşar, 2003: 126). Osmanlı Devleti, fethederek hâkimiyet kurduğu yerlerde İslam dininin bu kuralını uygulamaya koymuş (İnalcık, 2019: 16), müslüman ve gayrimüslim tebaadan hemen hemen aynı şeyleri talep etmiştir. Devlet, bünyesinde bulunan topluluklardan öncelikle itaat ve sonrasında da vergi istemiştir. Ters açıdan bakılıp tahlil yapılacak olunursa gayrimüslimler de devletten can güvenliği, vergide adil olma, ibadet ve inanç serbestisi gibi beklentiler içerisindedir (Adiyeke, 2014: 10).

Osmanlı Devleti Balkan Yarımadası, Ortadoğu ve Kuzey Afrika'yı kapsayan geniş bir toprak sahasına sahip olduğu için birbirinden oldukça farklı toplumları bünyesinde bulundurmaktaydı. $\mathrm{Bu}$ kalabalıkları bir arada tutabilmek ve sağlıklı bir şekilde yönetebilmek için toplumu inanç temelinde sınıflandırmıştı (Sannav-Sezer, 2018: 161-162). Bu haliyle devletin içindeki gayrimüslimler, din ve mezheplerine göre (Ehl-i kitap olanlar ve olmayanlar) gruplandırılmışlardır. Müslümanlar tek bir millet, gayrimüslimler ise din ve mezheplerine göre ayrılarak farklı milletler olarak tanımlanmış, toplumdaki siyasal ve sosyal organizasyonlar buna göre oluşturulmuştur (Sofuoğlu-Akvarup, 2012: 74). Bu uygulama "millet nizamı" ya da "millet sistemi" olarak isimlendirilmiştir. Bireylerin sosyal hayattaki kimliklerini belirleyen esas etkenin din olduğu bu sistemde, halk -millet (milel) tabiri ile ifade edilmiştir. Bu yönüyle Millet Sistemi, İslam Hukuku'nun uygulanma şekline verilen isimdir. Ancak 'Millet sistemi' günümüzde anlaşılan şekliyle sadece bir ırkı veya rrkları temsil eden, "nation" anlamında kullanılmamıştır (Güneş, 2015: 11-13).

Büyük bir imparatorluk olan ve bünyesinde çok sayıda gayrimüslimi barındıran Osmanlı Devleti, II.Mehmet'in oluşturduğu millet sistemi ile sosyal hayatı düzenleme yoluna gitmiştir. $\mathrm{Bu}$ sayede her millet yani cemaat kendi aralarında organizasyonlarını kurmuş ve kendi gelenek görenekleri etrafında örgütlenmişlerdir. Dini cemaatlerin örgütlenen bu yapısı günümüzdeki tüzel kişiliklere benzetebilmektedir. Osmanlı Devleti bu 'tüzel kişilikleri' kendi bünyesinde tanımış, korumuş (Adıyeke, 1999: 260) ve vergi sistemi vasıtasıyla da denetlemiştir. Osmanlı Devleti'nin millet sistemi açısından en önemli dayanak noktası II.Mehmet'in her üç cemaat için de resmi devlet memuru statüsüne sahip birer "Millet Başı" tayin etmesidir (Adıyeke, 2014: 6). II.Mehmet 1453 y1lında İstanbul'u fethettikten sonra Rum, Yahudi, Ermeni milletlerine, imparatorlukta tanınmış topluluklara bazı özerklikler vermiştir (Braude, 1999: 245). II.Mehmet'in uyguladığı bu din politikası diğer adıyla "ekümenik siyaset"in amacı, imparatorluğu ve yeni başkentini farklı dinlerin merkezi haline getirme arzusunu içermektedir (Güneş: 16). Ermeni Kilisesi Piskoposu Joachim, Yunan Ortodoks Kilisesi'nin Patriği Genadios Scholarios, başhaham Moses Capsali, kendi dini otoritelerinin başkanları (Braude: 245) yani "Millet Başı"ları olmuşlardır. Ruhani liderler kendi cemaatlerinin evlenme, boşanma, vasiyet gibi meseleleriyle ilgilenmişler ve bazı küçük 
mahkemelerde kilise kanunlarına göre yargılama yapmışlardır (Küçük: 210). Ayrıca, gayrimüslim birtakım kişilerden cizye adında vergiler alınmıştır. Cizye, gayrimüslim tebaaya verilen hak ve din serbestisine karşıllık hasta, sakat olmayan, belirli bir yaş aralığında bulunan, kişi başına düşen yıllık vergilendirme sistemidir (Özcoşar: 135). Osmanlı Devleti'nin geliştirdiği bu sistem sayesinde çeşitli din ve mezhebe sahip topluluklar İslam medeniyetinin çatısı altında varlıklarını devam ettirebilmişlerdir. Bu sayede Orta Doğu, Kafkaslar ve Balkanlar'da asayiş sağlanabilmiştir (Küçük: 210).

\section{Balkan Milliyetçiliğin Oluşumu}

Modern milliyetçilik teorilerinin erken dönemlerini meydana getiren ilk yaklaşımlarda, milletler doğal bir öze, yapıya ait topluluklar olarak tanımlanmaktadır. Bu şekliyle millet-ulus, doğal farkındalık halini ifade etmekle beraber, bu durumun siyasal izdüşümünü oluşturan etno-kültürel ve politik alanları birbiriyle ilişkilendiren ideolojidir (Yalçıner, 2014: 195). Modern tarihin ana olgusundan biri olan milliyetçilik, coğrafî, iktisadî, politik, sosyal ve kültürel ortamlardan etkilenip farklı yerlerde ve farklı şekillerde gözükebilmektedir. Bu farklılıkların en fazla hissedildiği yerlerden biri olarak Balkanlar gösterilmektedir (Yetim, 2011: 294). Tarih boyunca Balkanlar milliyetçilik ve etnik kimliklerin farklılığına sahip olan bir yarımada olmuştur. Balkanlar, İmparatorluk ruhuna Kuzeybatı Avrupa'dan çok önceleri sahip olmuştur. Nitekim Roma-Bizans imparatorluklarının hâkimiyeti altındayken etnik aidiyetlerinin teşekkülünde ciddi sıkıntılar yaşamıştır. Bu nedenle de etnik teşekkülün ‘sert çizgilerine' yani tarih bilincine sahip olmuştur (Ortaylı, 1985: 999).

Balkan milliyetçilik hareketinin oluşumuna bakıldığında, bu uluslaşmanın-milletleşmenin Batı Avrupa milliyetçiliğini meydana getiren halkın yaygın tutumuna bağlı olan politik milliyetçilikten farklı olduğu görülmektedir. Bunun yanında dil, kültür, etnisite esasına dayanan Alman milliyetçiliğinden etkilenen kendine has bir yapısı da vardır. Örneğin Balkan toplumlarında, 16. ve 17. yüzy1llarda meydana gelen ve bilhassa Sirbistan ve Yunanistan'da ilerleyip neo-Bizans sanatı olarak isimlendirilen dönem, yeni ve oldukça ilgi çekici olmuştur. Bu dönem Balkan milliyetçiliğinin ilk nüveleri olarak değerlendirilmiştir (Yetim: 290). Bu nedenle Balkanlar'da ulusçuluk hareketleri incelendiği zaman bu hareketlerin ortaya çıkış tarihi 1789 Fransız Devrimi ile doğrudan ilişkilendirilememektedir. Çünkü 16. yüzyıl itibariyle Balkanlar bölgesinde hâlihazırda bazı kültürel ulusalcı işaretler bulunmaktadır. Balkanlardaki halkların milli bilince sahip olmasının nedeni onların Orta Çă̆'daki kendilerine ait devletlerinin ve kültürlerinin mirasçıları olmalarındandır (Ortaylı: 998). Osmanlı Devleti'nde, Fransız milliyetçiliğinden ve aydınlanmasından önce Balkanlarda Helenler ve Slavlar arasında milliyetçilik fikirleri oluşmuş̧ur. Balkan milliyetçilerine 15. yüzyılda Ivan Gunduliç, 17. yüzyılda ise Jurac Krijanic gibi Slav irredantist şair ve din adamları örnek gösterilebilir. Balkanlardaki topluluklar-kavimler geçmişlerinde kendilerine ait devletlere, bağımsız kiliselere ve de yazılı edebiyata sahip olan toplumlardır. Bu kavimlerin milliyetçileri belli dönemlerde İtalya'dan düşünce ve bilim öğrenerek Polonya'dan politik olarak destek bile beklemişlerdir. Zira o dönemin koşullarındaki kimlik ve milliyetçilik algısı bireyin dinine göre şekillenmektedir. Birey Polonyalı ise Katolik, Rus ise Ortodoks ve Türk ise Müslüman olarak algılanmaktadır. Bir süre sonra ise özellikle Balkanlar'da yeni bir ümit olarak Rusya görülmüş ve Bizans Hristiyanlığının yerini zamanla Slavlık almaya başlamışıtır (Ortayl1, 2012: 22).

Osmanl1-Rus Savaşı sonrasında 1774'te imzalanan Küçük Kaynarca Anlaşması ile Rusya Ortodoks tebaa üzerinde koruyucu olma hakkı elde etmiş ve Rusya'ya karşı bu hakkı kullanan Büyük Güçler, isteklerini zaman içinde genişletmiş ve milletler sorununu ortaya çıkarmışlardır (Yetim: 289). 19.yüzyıla kadar Osmanlı Devleti içindeki halkları bir arada tutmaya yarayan millet sistemi çökmeye başlayınca yükselen milliyetçilikle beraber Balkanlarda dinsel aidiyetten ziyade etnik aidiyetin ön planda tutulduğu devletleşme süreci başlamışsa da 'Ortodoks'luk bölgede önemli bir konumda olmaya devam etmiştir. Ortodoksluk, Balkan Milliyetçilikleri bağlamında incelendiğinde, 
dini olarak Müslüman halka karşı "öteki”nin de var olduğunu hatırlatan önemli bir kimlik haline gelmiştir. (Sadoğlu: 7). Rusya ise Ortodoksluk bilincini her daim yaymaya çalışarak kendi lehine kullanan bir siyaset izlemiş̦tir (BOA, HAT, Nr. 33311). Bu dönemde din milli bir kimliğe bürünüp diğer dinlerden ayrışacaktır (Mazower, 2014: 122). Ortodoksluk (genel olarak din) Osmanlı İmparatorluğu sona erdikten sonra da Balkanlar'daki politik rolünü devam ettirmiştir. Balkan coğrafyasında bulunmakta olan milli kimliklerin temellerinin dinsel aidiyet üzerinden şekillendiği söylenebilmekle beraber bu tespit çoğunluğu Ortodoks Hristiyan olan Sirp, Karadağ, Bulgar, Rumen, Yunan, Makedon halklarının sadece tek bir ulus-devlet şeklinde birleșip toplanamama sebeplerini açıklayamamaktadır(Sadoğlu: 2). Balkan milliyetçiliklerinin bazılarının ise tarih bilincine geç ulaşmış olması nedeniyle "yanlış kimliği" açıkladıkları ve üzerinde gereğinden fazla durdukları görülmektedir. Ayrıca Balkan milliyetçilikleri (Türk ve Arnavutlar hariç) Balkan devletlerinin ve milletlerinin olduğu kadar dış kesimlerden de desteklenmiştir (Ortaylı: 2). Osmanlı devlet sisteminde, 'millet' adı ile cemaatsel olarak ifade edilen Gayrimüslimler, özgürlük, hak, adalet, eşitlik gibi unsurlarla ve de Büyük Güçlerin tesiriyle siyasi-politik yönden bilinçlenmiş ve ayrıllkçı hareketlere yönelmişlerdir (Yetim: 289).

19. yüzyılda Balkan halkları açısından bakıldığında, çeşitli nedenlerle ayrışmalar ve bağımsızlık hareketleri görülmüştür. Bu dönemde Orta Avrupa üzerinden Balkanlar’a yayılan milliyetçilik akımı, ticaretin gelişimiyle birlikte orta sınıfın meydana gelmesi, Rus Çarlığı'nın PanSlavist genişleme politikaları, Viyana Düzenlemeleri (1815) ile toprak bütünlüğünün sağlanacağına dair mevcut olan ilkenin terk edilmesi gibi nedenler Balkan halklarının ulus-devletleşme için adım atmalarına zemin hazırlamıştır (Sadoğlu: 6). I. Dünya Savaşı öncesindeki artan milliyetçilik hareketleri ve savaş sonrasında "ulusların kendi kaderini tayin hakkı", yapılan konferanslar, anlaşmalar sonucunda, ulus ve ulus-devlet inşasına başlanmıştır. Bu inşa sürecinde de elbette ki dönemin büyük güçlerinin etkileri olmuştur. Balkanlardaki milliyetçilik akımları, Fransız İhtilali'nin yaydığı fikirler, Rus Panslavizmi, yerleşmiş bulunan dil, din ve kilisenin etkisi gibi birçok bileşenin varlığ 1 sonucunda oluşmuştur (Aydın, 2010: 117). Stefanos Yerasimos'a göre "Bu durumda Balkan ve Orta-Doğu milliyetçilikleri, Batı'nın ideoloji cephaneliğinden, var olan uluslart a posteriori (sonradan) haklı kilan ve a priori (tanım gereği) yeni uluslar yaratmaya olanak veren bir takım gerçekler bulup" (Yerasimos, 1994: 20) çıkarmışlardır. Her etnik kimlik, kendi etnisitesinin ve dilinin önemli olduğunu vurgulamakta ve de genellikle ulus-devlet olma nedenini geçmişte kendilerince acı ile dolu olan tarihlerine ve mitlerine dayandırmaktadır. Bu durum Yerasimos'un ifade ettiği gibi, milliyetçi ve ayrılıkçı hareketlerin kendilerini savunurken başvurduğu unsurların sacayağını oluşturmaktadır.

Avusturya, Türkiye, Rusya gibi çok farklı uluslara sahip olan imparatorlukların devlet yapıları milliyetçiliğin artmasıyla beraber zayıflamıştır. Bu durum 19. yüzyılda Avrupa haritasının yeniden şekillenmesine ve çizilmesine neden olmuştur (Heywood: 167). Batı'da milletleşme, her ulusun kendi milli kavram, ekonomik araç ve sosyo-kültürel yapılarını kurmalarına imkân sağlayan ve uzun yıllar süren evrimleşme sonucu oluşmuştur (Yerasimos: 20). Balkanlarda ise, "Milli Kimliğin" gelişme aşamaları, dini kimliklerin genişleyip büyüyerek etnik kimlikleri de içine almasıyla oluşmuştur. Milli kimliği ifade etmede ilk araç kiliselerdir (Karpat, 1999: 21). Dinin Balkanlardaki hâkimiyeti, Osmanlı Devleti'nin 'Millet Sistemi' ile yarattığı 'cemaat' kavramı ile dolaylı bir şekilde gerçekleşmiştir (Sadoğlu: 7). Kemal Karpat, Balkanlar' daki milliyetçiliğin dinsel ve etnik kimliklerin karışımıyla ortaya çıkan bir niteliği olduğu için 'cemaat millliyetçiliği' tabirini kullanır ve bu yönünden ötürü Balkan Milliyetçiliğini ayrı bir yere koymaktadır. Karpat'a göre Balkanlardaki milliyetçilik kendine has 'Popüler yaşamsal bir cemaat' birlikteliğine sahip olduğu için ayakta kalmaktadır (Karpat, 2004: 13). Bu nedenle Doğu Avrupa ve Balkanlar'daki milliyetçilik türü diğer milliyetçilik türlerinden farklıdır. Emperyal devletlerin hâkimiyeti altında olduğunu düşünen halkların, baskılardan kurtulma planları için bir amaç taşımaktadır. Burada Balkan halklarının öncelikli amaçları bağımsızlık mücadelesi başlatmanın dışında ulus fikrini ve bilincini 
halka aşılamaktır (Aydın: 117). Bununla birlikte milliyetçilik tarihine bakıldığı zaman milliyetçiliğin Balkan halkları üzerinde çok iyi izler bırakmadığı görülmektedir. 19. yüzyılda Balkanlarda ulus ve ulus-devlete sahip olma düşüncelerinin eş zamanlı olarak gelişimi beraberinde ortak bir düşman yaratmıştır. Ortak düşman yani komşu 'azınlıklar'dan kurtularak bir an öce ulus-devlete sahip olma düşüncesi gelişmiştir (Yerasimos: 35).

\section{Bulgaristan'ın Tarihsel Makedonya Hayali}

Bir bölgede ilk olarak bulunmuş ya da bulunuyor olmak milliyetçilik teorisine göre oldukça önemlidir. Devletler bölge üzerindeki hak iddialarına bu şekilde yasal dayanak sağlamaktadır. Bu bağlamda hemen hemen bütün Balkan ülkeleri bölge üzerinde ilk kendilerinin var olduğunu ileri sürdükleri için Balkanlar'daki temel sorunların bir kısmı bundan kaynaklanmaktadır. Buna Yunanistan ve Bulgaristan'ın, Makedonya bölgesi üzerinde tarihsel olarak ilk kendilerinin bulunduklarına dair karşılıklı çabaları ve bu nedenle bölgede temel hak sahibi olduklarını ileri sürdükleri pek çok iddia örnek gösterilebilir. (Mansel, 2004: 508). Makedonya'nın tarihçesine bakıldığ1 zaman görülebileceği üzere Doğu Roma İmparatoru II. Basileous, 1018'de Samuil İmparatorluğu'nu yıkmış ve bölgeye yeniden hâkim olmuştur. Bölge üzerindeki Doğu Roma İmparatorluğu'nun hâkimiyetine Bulgarlar son vermiş, Bulgarların hâkimiyetine ise 14. yüzyılda Sırplar son vermişlerdir. Osmanlı Devleti ise 1389 yılında Kosova Savaşı sonrasında Makedonya bölgesini kendi topraklarına katmış ve bölgede 500 yıldan daha uzun bir süre Osmanlı hâkimiyeti hüküm sürmüştür (Saatçi, 2002: 47-48).

Osmanlı Devleti'nin toplumu organize ettiği millet sistemi Yunanistan'ın 1829 yılında bağımsızlı̆̆ını elde etmesiyle parçalanmaya başlamıştır. Bu durumun Balkanlardaki toplulukların bağımsızlık talepleri için bir örnek oluşturduğu söylenebilir. Çünkü Yunanistan'ın bağımsız olmasıyla birlikte Osmanlı topraklarından ilk kez yeni bir devlet ortaya çıkmıştır (BOA, DH. MKT, 2724/92, 8M1327). Osmanlı Devleti'nin zayıflamaya başlaması sonucunda 1839 yılında ilan edilen Tanzimat Fermanı imparatorluktan kopuşları önlemek için atılan önemli bir adımdır. Bu nedenle 19. yüzyıl'da geleneksel olarak anlaşılan şekilde parçalanmaya başlayan Millet Sistemi, resmi olarak tanımlanan ve reform niteliği taşıyan Tanzimat programında yer almıştır (Braude: 252). Nitekim Avrupa'daki Büyük Devletlerin baskılarının da etkisiyle Gayrımüslim cemaatlerin Türk ve Müslüman olan cemaatlerle ortak yaşayabilmelerini düzenleyen (Küçük: 212) Tanzimat Fermanı aracılığıyla, Müslümanlar ve Gayrimüslimler kanun önünde eşit sayılmıştır. Bununla birlikte 1839 Tanzimat Fermanı müslüman halklara anayasa vermediği halde, 1856 Islahat Fermanı gayrimüslimlerin milli bağımsızlıkları için manifesto niteliği taşımıştır (Küçük: 214). 1856 Kırım Savaşı ile kapitalizmin yerleşmeye başladığı Balkanlarda 1878 Berlin Anlaşması sonrası emperyal aşamaya geçilmiş, bu sefer de Büyük Devletlerin Balkanlardaki etkisi daha yoğun ve karışık olmuştur (Yetim: 287).

1877-1878 Osmanl1-Rus Savaşı (93 Harbi) sonrası imzalanan Ayastefanos Antlaşması'yla (3 Mart 1878), Bulgaristan, kuzeyde Tuna boyundan Balkana, Kavala'dan Selanik'e kadarki Ege kıyılarına, Karadeniz'den Makedonya'daki Ohri gölüne kadar uzanan oldukça büyük bir bölgeyi topraklarına katma hakkına sahip olarak tarihî emellerine ulaşabilmek için önemli bir basamak elde etmişti (BOA, Yıldız Sadaret Hususî Maruzat Evrakı (Y.A. Hus.) No: 225/64 Lef 1,6,9,23 Cemaziyel Âhir 1309/24 Ocak 1892). Ayrıca Osmanlı Devleti’ne vergi bağıyla bağlı özerk bir prenslik kurma şansı da elde etmişti. Bulgaristan açısından bu geniş toprak sahasına sahip olunduğu zaman 1000 yıl öncesindeki "bütün Bulgarların ve Greklerin çarı ve mutlak hâkimi" unvanını almış olan I.Boris'in Ortaçağ İmparatorluğu'nun sınırlarına erişilmiş olunacaktı (Yalçınkaya, 2017: 324). Ancak Avrupa devletleri Bulgaristan'ın toprak sahası bu denli genişlediğinde Rusya'nın Bulgaristan sayesinde bölge üzerinde avantajlı konuma geleceğini düşündüklerinden Ayastefanos Anlaşması değiştirilerek yerine imzalanan Berlin Antlaşması ile Bulgaristan'ın elde ettiği topraklara kısıtlama getirmiştir. Berlin Antlaşması sonucunda Bulgaristan'a verilen topraklar ikiye bölünmüştür. Doğu Rumeli, 
Makedonya ve Batı Trakya Osmanlı'ya geri verilmiştir (Başkaya, 2015: 55). Makedonya bölgesi yaklaşık beş buçuk asır Osmanlı Devleti'nin hâkimiyeti altında kalan bir bölge olmuştu. Ancak 19. yüzyıl sonu ve 20. yüzyıl başında sosyo-ekonomik nedenlerden dolayı bağımsız ve yarı-bağımsız devletler için gözde bir yer haline gelmiştir. Ayastefanos ve Berlin Anlaşmaları sonucu bölgedeki toprakların paylaşımında yaşanan sıkıntı da "Makedonya Sorunu"nu meydana getirmiştir (Erol, 2017: 283).

Osmanlı Dönemi Makedonya's1 üzerinde yaşanan süreç içerisinde özellikle 1877-1878 Osmanlı-Rus Savaşı (93 Harbi)'nin bir kırılma olduğu görülmektedir. Bu savaş sonrasında önemli bir göç hareketinin yaşandığı da bilinmektedir. (BOA, Y.A. Hus., No: 162/87 lef 1-3, 11Zilkade 1296-27 Ekim 1879). Bu savaşin sonunda Balkanlar'da meydana gelen ve uzun yıllar devam eden karışıklıkların en mühim nedeni bölgedeki devletlerin bu toprakları aralarında bölerek paylaşma arzusu olmuştur (İnat-Balc1, 2010: 640). Balkanlardaki topraklar üzerinde kendince emelleri olan Bulgaristan'ın "Büyük Bulgaristan" hayalinin ana teması da Makedonya'ydı. Tamamı Osmanlı Devleti'nin elinde olan bu bölgede Türk ve Arnavut gibi Müslümanların yanında 'Makedonyalı' olarak adlandırılan Slav ve Rum kökenliler yaşamaktaydı. Bulgaristan'daki bir grup araştırmacılar söz konusu Slavların konuştuğu dil ile Bulgarca'nın yakınlığına dikkat çekmiştir (Lütem, 2000: 22). $\mathrm{Bu}$ nedenle Bulgarlar Makedonya'da Slavca konuşan bu halkı kendi saflarına çekmek için bir dizi uygulamalarda bulunmuştur. Bulgarlar milliyetçiliği yaygınlaştırabilmek adına Osmanlı Devleti'nden 11 Mart 1870 tarihli Osmanlı Padişahı'nın fermanıyla kendilerine ait bağımsız, 'millı̂' bir kiliselerinin olması talebinde bulunmuştur. Bulgar milliyetçileri, Rum ve Bulgar kiliselerinin ayrılmasını sağladıktan sonra Bulgar halkı üzerindeki milli bilincin inşa sürecini başlatmışlardır. Kendi bilinçlerini başka dimağlara aşılamak amacıyla okullar kurmak istemişlerdir. Kurmak istedikleri okullar kiliselere bağlı bulunduğu için iletmek istekleri mesajları doğrudan kendi cemaatlerine ve yeni yetişen nesillere aktarabilme imkânına ulaşmışlardır (Armaoğlu, 2003: 582).

Milliyetçilik akımı, Rusların Panslavizm politikası ve Fener Rum Ortodoks Patrikhanesi'nin Bulgarlar üzerindeki etkisi Bulgarları isyan etme ve ayrıllkçı hareketler sergilemeye teşvik etse de halk tarafından tam manasıyla bir destek verilmemiştir. Ancak bir süre sonra Paisii, Sofroni, Neophtos gibi Bulgar papazları ve Jorge Venelin gibi Rus filoloğun katılımlarıyla bu hareketler destek bulmuş ve Bulgarlarda bağımsızlık düşüncesi oluşmaya başlamıştır (Yalçınkaya: 323). Böylece Bulgarlar, Makedonya'daki halkı ikna edip kendi saflarına çekmek için papazları ve öğretmenleri görevlendirmişlerdir. Bunlar yaptıkları propagandalarla, Makedonya'yı birleşmeye razı etmeye çalışmışlar, bunun için farklı farklı yollar da denemişlerdir. $\mathrm{Bu}$ şekilde Bulgarlaşma faaliyetleri yürütülmeye çalışılmıştır. Makedonya'da bulunan Bulgarlar keşmekeş bir ortam yaratarak bu ortamdan diğer devletlerin de haberdar olup duruma müdahale etmelerini istemişler ve bu amaçla örgütlenmeye başlamışlardır. Organize hareket etmeleri sonucunda oluşturdukları ilk örgüt 1890 yılında Sofya'daki “Merkezî Trakya-Makedonya Komitesi”dir. Bu komite-örgüt Makedonya'dan göç eden Bulgar göçmenler için kurulmuş gibi gözükmekle birlikte zaman içerisinde siyasi amaçları gerçekleştirmek isteyen bir pozisyonda yer almıştır (BOA, Bİ, NR. 953; Armaoğlu: 580-583).

Bulgaristan'da bulunan siyasi firkaların çoğu, Sofya'daki komiteler için destek vermeye hazır konumdadır. Serbest ve muhafazakâr fırkaların fikirleri ortak olduğu için aldıkları kararlarda da 'Bulgaristan'ın politikası hangi firka için olursa olsun Ayastefanos Antlaşması'nın hükümlerini yerine getirmek ve Şarkî Rumeli'ye yaptıkları hücum gibi bir gün ansızın Makedonya'yı işgal edebilmektir" diyerek bunu belirtmişlerdir. Berlin Antlaşması ile Ayastefanos'taki hükümler geçersiz kalsa da Bulgarlar hedeflerinden vazgeçmemişler ve bu hedefleri gerçekleştirmeye yönelik çaba sarfetmiş̧lerdir (Alben 2009: 82). Fakat Avrupa Devletleri, Makedonya bölgesinde huzursuzluk çıkartmaya yönelik olan Bulgaristan'ın bu tutumunu sürdürmesinin sadece kendilerine güçlük yaratacağını ifade etmişlerdir. Özellikle İtalya bu tutumdan son derece rahatsız olmuş ve Avusturya, Almanya ve İngiltere'yle konunun hallolması için Sofya'da bir görüşme yapmıştır (Gounaris, 1993: 
5). Makedonlar ise, yürütülen faaliyetlere karşı direnç göstererek kendi bağımsızlıkları için adım atmaya başlamışlardır. İvedilikle halkı devrim fikrine teşvik ederek ilk adımı atarlarken "Sırp propagandasının halkı parçalaması"ndan da endişelenmişlerdir. Buna karşılık olarak ise Bulgar örgütleri kurulmuştur (BOA, Bİ, NR. 684). 1893 y1lında Selanik'te "Makedonya Dâhili İhtilal Teşkilatı" (Makedonya Komitesi) adıyla yeni bir örgüt kuran Makedonyadaki Bulgarlar, Makedonya'nın özerkliğe sahip olması için çalışırken çizdiği sınırların içerisine bir süre sonra Edirne'yi de dâhil etmiştir. (Uzer, 1999: 117).

1897 'de Avusturya ve Rusya'nın Balkanların merkezinde yaşanan bu hadiselere kendilerini dâhil etmeleriyle mesele uluslararası bir nitelik kazanmıştır. Rusya ve Avusturya arasında bir anlaşma yapılmış ve bu anlaşmanın amacı da 'Balkanlarda yeni bir düzen kurulacak kadar ileri gidilmesini engellemek' olarak duyurulmuştur. Devletler kendi aralarında Balkanları paylaştıkları takdirde Yanya ve İşkodra gölleri arasında bir "Müstakil Arnavut Prensliğinin" kurulmasına, Avusturya'nın Yeni Pazar'ı ve Bosna-Hersek'i ilhakına ve arta kalan toprakların da diğer Balkan Devletleri arasında paylaştırılmasına karar vermişlerdir. Fakat Bulgar Prensliği böylesi bir durumun kendi çıkarlarına ters düşebileceğini öngördüğünden, Makedonya bölgesinde özerk bir idarenin kurulması hususunda Osmanlı Devleti'ne başvurmuştur (Bayraktar, 2014: 6). Osmanlı Devleti'ne sunulan teklifin sadece Bulgar Prensliği açısından avantajı olduğundan Avusturya, Rusya ve Osmanlı teklife sıcak bakmamışlardır. Planları sekteye uğrayan Bulgarlar, komitelerin faaliyetlerini arttırmaya devam etmiştir. Bu şekilde, 1899 - 1900 yılında Sofya'daki Makedonya Bulgar Komitesi delegeleri aracılığıyla genel isyan hareketi başlatmayı hedeflemişler ve Osmanlı sınırları dâhilindeki Arnavutlara silah ve cephane göndermeye başlamışlardır. Bulgarlar, Makedonya bölgesindeki düzeni bozmak için bunun gibi uygulamalara devam etmişlerdir. İlerleyen süreçte de komiteler, silah, cephane ve teçhizat gönderebilmek için para toplamışlardır. Ayrıca Bulgarlar propaganda yaparak dikkatleri kendilerine çektikleri için Avrupa devletleri bölgede 1slahat çalışmalarına yönelinmesini ve özerk bir yönetim olmasını teklif etmiştir Makedonya'da bu duruma benzer örnekler çoğalmaya başlayınca Osmanlı Devleti de yaşanan hadiselere reaksiyon göstermeye başlamıştır. (Glenny, 2000: 172). Örneğin, 29 Temmuz 1908'de 3'üncü Ordu'dan Sadarete çekilen telgrafta Selanik'e ulaşan İstan, Bulgar ve Rum çete sayılarının 200'e ulaştığı belirtiliyordu. Sayılarının git gide arttı̆̆ bu çetelerin hareketlerine karşılık Osmanlı Devleti de bazı müdahelelerde bulunmuştu (BOA, Y. PRK. ASK, 259/32).

Sultan Abdülhamid ve hükümeti ise bölgedeki konu ile alakalı uzun görüşmelerde bulunduktan sonra 1902'de Islahat hazırlıklarına başlamış ve tamamlanan Islahat planını da hemen hayata geçirmiştir. "Rumeli vilâyetleri hakkında talimat" adını alan yeni 1slahata göre valilerin yetkileri genişletilmiş, karma jandarma teşkilâtı oluşturulmuş, mahkemelerin bağımsızlığı sağlanmış ve islahatın kontrolü vezir rütbesindeki bir umumî müfettişe verilmiştir (Uzer: 84-87). Avusturya ve Rusya ise açıklanan bu sslahatlara şiddetle karşı çıkmışlar ve "Mürzteg şehri toplantısında" alınan kararın uygulanmasını istemişlerdir. Buna göre Makedonya maliyesi İstanbul'dan ayrı olacaktı. Ayrıca Büyük devletler maliye için delegeler gönderecek ve Makedonya'da "umumi meclis" açılacaktı. Osmanlı Devleti bu kararlar ile ilgili olarak 'Umumi Meclis' ile ilgili kararı onaylamamış sadece maliye delegelerinin gönderilmesini kabul etmiş̧ir. Uygulamaya konulan kararlar ve yaşanan süreç Osmanlı Devleti'nin söz hakkının eskisi gibi olamayacağına işaret etmektedir. Tüm uygulamalara rağmen bölgede sorunlar çözülememiş ve çatışmalar devam etmiştir (Okur, 2012: 32$33)$.

1903 yılında Balkanlardaki mesele tüm büyük devletleri ilgilendiren bir boyut kazanmaya başlamış ve özellikle Makedonya bölgesi bu devletlerin paylaşım sahası haline gelmişti (BOA, Bİ, NR.1083). 3 Şubat 1908'de Petersburg'da Başbakan Stolıpin'ın başkanlığında Yakındoğu ve Balkanlar'daki sıkıntı ve karışıklıkların görüşülmesi amacıyla meclis toplanmıştır (Saylak, 2016: 129). Bu toplantıda Balkanlar'da yaşanan gelişmeler hususunda görüşlerini açıklayan Rusya Dışişleri Bakanı İzvolskiy, Osmanlı Devleti'nin 1slahat konusunda sorun çıkardığını ve bunun ancak 
büyük devletlerin askeri müdahaleleri ile önlenebileceğini ileri sürmüştür. Buna ek olarak bölgede Avusturya-Macaristan'ın Dışişleri Bakanı'nın izlemiş olduğu politikanın Balkan devletleri ve de Rusya açısından yanlış bir hamle olduğunun altını çizmiştir. Böyle bir durumda çatışma çıkması sonucunda Rusya'nın önlenemeyeceğini belirtmiştir. Bu durumu 'Rusya Balkanlar'daki duruma müdahale etmezse, asırlardan beri verdiği mücadele sonuçsuz kalır ve bölgede büyük bir güç olmaktan çıkar. Bu nedenle tek çılkar yol İngiltere ile anlaşmaktır' ş̧eklindeki sözleriyle ifade etmiştir. Bu konuda İngiltere Büyükelçisi ile yaptığı görüşmesinde iki devletin Osmanlı Devleti'ne karşı ortak askeri harekâta geçmesi için konjonktürün uygun olduğunu belirtmiştir (Hacısalihoğlu: 170-175).

Rusya'nın hâkimiyetine son vermeyi hedefleyen İngiltere kralı VII. Edward, Rus çarı II. Nikola'ya 1908 yılında Reval'de görüşme teklif etmiş ve bu görüşmelerin neticesinde alınan kararlarla Makedonya, jandarma bölgelerine ayrılmıştır (BOA, Y.PRK. MK, 22/101). Selânik - Rus, Drama - İngiliz, Serez - Fransız, Kosova - Avusturya, Manastır vilâyeti ise İtalyan jandarma reform örgütüne verilmiştir. Osmanlı Devleti Reval Kararlarından haberdar olduğunda Sultan II. Abdülhamit, kararların yumuşatılması için mümkün olduğunca çalışmıştır. Ancak yine de kurulması tasarlanan Makedonya Özerk Yönetimi'yle, Arnavutluk da Osmanlı Devleti'nden ayrılmıştır. Bunun sonucunda genelde Hristiyan tebaa özelde ise Bulgarlar durumdan oldukça hoşnut olsalar da Rumlar durumun kendi çıkarlarına ters düştüğünü anlayarak 1907-1908'de Bulgarlar aleyhine faaliyete girişmişlerdir. Rum çeteler Makedonya'daki Bulgar köylerini yağmalayıp insanları öldürmeye başlamışlardır. Osmanlı Devleti'nin bölgedeki zayıf otoritesi Reval kararları ile sona doğru yaklaşmıştır. (Hacısalihoğlu, 2008: 424). Ancak Reval kararlarının çıkardığı bu kargaşalar Osmanlı Devleti'nin içinde muhalif bir örgütlenme ortaya çıkmasına da neden olmuştur. Bu kargaşa ortamında Reval'de alınan kararların engellenebilmesi, Rumeli ve Makedonya'nın kurtarılması ve Meşrutî yönetimin kurulması amacıyla İttihat ve Terakki Cemiyeti kurulmuştur. Cemiyet zamanla etkinliklerini uygulamaya koymuş ve de genişletmişsir. 1907'den itibaren İttihat ve Terakki Cemiyeti gün geçtikçe güçlenerek taraftar bulmuş ve Abdülhamid yönetimine karşı direnmeye başlamıştır. Çabalarının sonucunda meşrutiyetin ilan edilmesini sağlayarak iktidara gelmiş ve Reval kararlarının uygulanması engellemiştir. Ancak yine de Makedonya'daki sıkıntılar için tam bir çözüm bulunamamıştır (Alben: 87).

Bulgaristan, Sırbistan ve Yunanistan'1n, Balkanlar ve de Makedonya üzerindeki paylaşım mücadelesi devam etmiştir. Bunun sonucunda bu Balkan ülkeleri Osmanlı Devleti'ne savaş ilan ederek I. Balkan Savaşı'nı başlatmıştır. Savaşta Karadağ da Osmanlı Devleti'nin karşısında ve diğer devletlerle birliktelik halinde olmuştur (BOA, HR. SYS No: 1965/1). Fakat İstanbul yakınlarına kadar gelen ve Trakya'yı ele geçiren Bulgaristan'ın "Büyük Bulgaristan” olarak ortaya çıkması Osmanlı Devleti'ne karşı savaşa katılan diğer devletlerin bu kez Bulgaristan'a karşı II. Balkan Savaşı'nı başlatmalarına neden olmuştur. 1913'teki Bükreş Anlaşması'yla I.Balkan Savaşı sonucunda kazandıklarını büyük oranda yitiren Bulgaristan'ın elinde sadece Rodoplar dâhil Ege denizine kadarki Batı Trakya kalmışıtı (Kamil, 2017: 548-549). Balkan Savaşları'nın sonucunda düş kırıklığı yaşayan Bulgaristan, daha öncesinde alamadığı toprakları kazanabileceği ümidiyle 14 Ekim 1915 'te I. Dünya Savaşı'na katılmıştı. Bulgaristan kendi emelleri adına bu savaştan önemli kazanımlar elde edeceğini umuyordu.(BOA, HR. SYS No: 2324/1). Ancak müttefiklerinin Makedonya bölgesine asker yollaması sonucunda Sirbistan ve Yunanistan'a karşı başarısız olmuştur. Bulgaristan 27 Kasım 1919'da Neuilly Anlaşması ile Dobruca'nın Romanya'ya ve Batı Trakya'nın Yunanistan'a verilmesini öngören anlaşmayı kabul etmiştir (Lütem: 24). Bulgaristan'in 1915'de I. Dünya Savaşı'na, 1941'de ise II. Dünya Savaşı'na dâhil olmasının nedeni, 1913 Haziran-Ağustos döneminde öteki Balkan Devletleri'ne kaybettiği Balkan topraklarını geri alma amacını taşımasıdır. Bir anlamda bu iki Dünya Savaşı Bulgaristan için Balkan Savaşı'nın devamı olmaktadır (UludağKaragül, 2015: 3020). 
Günümüzdeki Bulgaristan ile Makedonya'nın yaşadığı ihtilaflar değerlendirilecek olunursa, Bulgaristan, Makedonya'nın bağımsızlığından sonra onu tanıyan ilk devletlerden birisi olmuştur. Ancak Bulgar hükümetleri, Makedonların Bulgar kimliğine sahip olduklarını öne sürmektedir. Ayrıca, Makedonca'nın, Bulgarcanın eski bir diyalekti olduğunu iddia etmektedir. Hatta daha da ileri giderek Makedon ulusunun tanınmasının Bulgarların öz tarihinin inkârı olarak değerlendirilebileceğinden hareket ettikleri için kendi ülkelerindeki Makedonları azınlık statüsünde kabul etmemiştir (Durmaz: 63). Görüldüğü üzere Bulgaristan'ın Makedonya'yı tanımasının altında yatan neden geçmişteki Büyük Bulgaristan düşüncesiyle alakalıdır. Bu nedenle hâlen dil ve ulus yönüyle özdeş olduklarını kanıtlamaya çalışmaktadır. Bulgaristan, Makedonya'yı "Ayestefanos Bulgaristan"1 çerçevesinde değerlendirmektedir. Büyük Bulgaristan, Büyük Makedonya gibi idealler devletlerin stratejik planlarının bir parçası olduğu için (Ağaoğlu: 2019) geçmişe referans veren ve bugüne uyarlanan uygulamalar devam etmektedir.

\section{Sonuç}

Balkanlar, tarihi geçmişlerinde Osmanlı Devleti'nin egemenliğinde yaşamış toplulukların bulunduğu bölgedir. Osmanlı Devleti, kimlik portföyünü din bazında oluşturmuştur. 'Din' kimliktir. İmparatorluk içindeki unsurlar kendilerini dini mensubiyetlerine göre tanımlamışlardır. "Millet Sistemi" deyim yerindeyse, Balkanları tek bir şemsiye altında birleştiren ideal bir hukuki, ekonomik ve sosyal bir toplum düzenidir. Ancak zaman içinde milliyetçilik akımının ortaya çıkmasıyla Balkanlardaki topluluklar 'din dışı' kimliklerini (milli kimlik) hatırlama arayışına girişmişlerdir. Artık öncelikli amaçları geçmişlerini hatırlayarak kimliklerini inşa etmek olmuştur. İnşa ettikleri bu yeni kimliklerini ise gelecek kuşaklara aşılama arzusu öncelikli hedefleri haline gelmiştir. Bu durum milliyetçiliğin oluşmasına ve bağımsızlık fikirlerine bir zemin hazırlamıştır. Eğitim ve din dolayısıyla da öğretmenler ve din adamları milliyetçiliğe sağlam temel oluşturup milliyetçiliği yaymak için bir araç olarak kullanılmıştır. Tüm bu uğraşların sonunda hatırlanan etnik kimlikler ise beraberinde ulus-devletleşme sürecini getirmiştir

Osmanlı Devleti'nin ve de uyguladığı millet sisteminin zayıflamaya başlarken milliyetçiliğin yükselmeye başlaması gibi nedenler sonucunda Balkanlardaki toplulukların bağımsızlık talepleri artmıştır. Yeni devlet kuran ulus-devletlerin ise sınırlarında değişiklik yapmak istedikleri görülmektedir. Bunlardan biri olan Bulgaristan'ın Makedonya üzerinde bazı tarihi iddiaları bulunduğu bilinmektedir. Çalışmada milliyetçilik bağlamında bir bölgede hak iddia etmenin, o bölgede çok eskiden beri var olduğunu ispatlamaya çalışmakla doğru orantılı olduğuna değinilmiştir. Bu nedenle Bulgaristan Orta Çağ'da sahip olduğu geniş sınırlara tekrar sahip olma düşüncesini genelde canlı tutmaya çalışmış ve politikasını bu şekilde yönlendirmiştir. Dolayısıyla Orta Çağ'dan beri o bölgede bulunduğunu kanıtlama ihtiyacı hissetmiştir. Çünkü 'Büyük Bulgaristan' politikasının ana ekseni Makedonya'ya sahip olabilmektir. Bulgaristan'ın I. Balkan Savaşı, II. Balkan Savaşı, I. Dünya Savaşı ve hatta II. Dünya Savaşı gibi pek çok savaşa ard arda katıldığı da göz önünde bulundurulduğunda Makedonya üzerindeki emelleri için hayallerini canlı tuttuğu net bir şekilde görülebilir. Bu hayali yahut amacı gerçekleştirebilmek için Bulgaristan kimi zaman ortodoksluk kimi zamansa etnik aidiyet ve dil üzerinden Makedonya'ya ya tekrar sahip olmaya çalışmıştır. Balkanlardaki diğer devletler de Bulgaristan gibi Balkanlardaki topraklarda çeşitli iddialar ortaya koymuştur. Oluşmakta olan bu yeni ulus-devletler geçmişteki tarihleri ve mitleri üzerine kendi varlıklarını inşa etmelerine rağmen bu mitlerin, ortak etnisitenin, dinin onların arasındaki ilişkileri güçlendirmediği bilakis çatışmaya sürüklediği görülmektedir. Nitekim her devletin gerçekleştirmek istediği kendi amaçları ve politikaları bulunmaktadır. I. Balkan Savaşı'nın sonucunun II. Balkan Savaşı'na yol açması buna verilebilecek örneklerden bir tanesidir. 


\section{Kaynakça}

\section{a. Arşiv Belgeleri}

--- Başbakanlık Osmanlı Arşivi, Bulgaristan İrade:

No: 953, 684, 1083.

---BOA, Dâhiliye Mektubi Kalemi:

2724/92, 8M1327.

-- Başbakanlık Osmanlı Arşivi, Hariciye Nezâreti Siyasî Kısım Evrakı (HR. SYS):

No: $2324 / 1$

No: $1965 / 1$

--- Başbakanlık Osmanlı Arşivi, Hatt-ı Hümâyun:

No. 33311.

--- Başbakanlık Osmanlı Arşivi, Yıldız Perâkende Askeriye:

No: $259 / 32$

--- Başbakanlık Osmanlı Arşivi, Yıldız Perâkende MK:

No: $22 / 101$

--- Başbakanlık Osmanlı Arşivi, Yıldız Sadaret Hususi Maruzat Evrakı (Y.A. Hus):

No: 225/64 Lef 1,6,9,23 Cemaziyel Âhir 1309/24 Ocak 1892.

No: 162/87 lef 1-3, 11Zilkade 1296-27 Ekim 1879.

\section{b.Araștırma Eserleri}

Adıyeke, N. (1999). Islahat Fermanı Öncesinde Osmanlı İmparatorluğu'nda Millet Sistemi ve Gayrımüslimlerin Yaşantılarına Dair, (Güler Eren, Ed.), Osmanl, Yeni Türkiye Yayınları, C.4, 345-357.

Adıyeke, N. (2014). Osmanlı Millet Sistemine Dair tartrışmalar ve Siyasal Bir Uzlaşma Modeli Olarak Osmanlı Millet Sistemi, Yeni Türkiye Dergisi, (60), 345-357.

Ağaoğlu, L. (2019). "Makedonya-Yunanistan İsim Kavgası" 25.11.2019. http://balkanpazar.org/siyasisorunlar_makedonya.htm

Alben, A. S. L. (2009). 93 Harbi'nin Balkan Cephesindeki Sosyo-Politik Sonuçları (1877-1908), Yayınlanmamış Yüksek Lisans Tezi, Mimar Sinan Güzel Sanatlar Üniversitesi Sosyal Bilimler Enstitüsü.

Anderson, B. (2009). Hayali Cemaatler Milliyetçiliğin Kökenleri ve Yayılması, (çev: İskender Savaşır) (5. Baskı), Metis Yayınları.

Armaoğlu, F. (2003).19. Yüzyll Siyasi Tarihi (1789-1914), Türk Tarih Kurumu Basımevi.

Aydın, S. (2010). Modernleşme ve Milliyetçilik, 2.Baskı, Gündoğan Yayınları. 
Başkaya, M. (2015). İngiliz Basınına göre Bulgaristan'ın Birinci Dünya Savaşı'ndan Çekilişi ve Selanik Antlaşması, Akademik Incelemeler Dergisi, 10(1), 51-74. https://doi.org/10.17550/aid.98003

Baumann, G. (2006). Çokkültürlülük Bilmecesi Ulusal, Etnik ve Dinsel Kimlikleri Yeniden Düşünmek, (Çev: Işıl Demirakın) Dost Yayınları.

Bayraktar, K. (2014). Makedonya Sorunu ve Avrupa Müdahalesi (1902-1905), Bilig - Türk Dünyast Sosyal Bilimler Dergisi, (69), 1-28.

Braude, B (1999). Millet Sisteminin İlginç Tarihi, (Güler Eren Ed.), Osmanl, Yeni Türkiye Yayınları, C.4, 245-254.

Carr, E. H. (1993). Milliyetçilik ve Sonrası, (çev: Osman Akınhay) (2.Baskı), İletişim Yayınları.

Delannoi G. (1998). Milliyetçilik ve İdeolojik Kataliz, (Jean Leca Ed), Uluslar ve Milliyetçilik, Metis Yayınları.

Erol, M. S. (2017). Makedonya Sorunu'nun Temel Dinamikleri, (Bilgehan A. Gökdağ- Osman Karatay Ed), Balkanlar El Kitabı 2.Cilt: Çağdaş Balkanlar, (3. Baskı), Akçă̆ Yayınları, 281-201.

Glenny, M. (2000). Balkanlar (1804-1899), Milliyetçilik, Savaşlar ve Büyük Güçler, Sabah Kitapları.

Gounaris, B. C. (1993). Steam Over Macedonia (1870-1912), East European Monographs Boulder, Columbia University Press.

Güneş, G. A. (2015). Osmanlı Devleti’nin Gayrimüslimlere Bakışı ve Klasik Dönem Millet Sistemi, Sosyal ve Kültürel Araştırmalar Dergisi, 1(2), 1-30.

Hacısalihoğlu, M. (2008). Jön Türkler ve Makedonya Sorunu (1890-1918), Tarih Vakfı Yurt Yayınları.

Heywood, A. (2011). Siyasi İdeolojiler, (Çev: Ahmet Kemal Bayram, Özgür Tüfekçi, Hüsamettin İnaç, Şeyma Akın, Buğra Kalkan), (3.Baskı), Adres Yayınları.

İnalcık, H. (2019). İstanbul Tarihi Araştırmaları Fetihten Sonra İstanbul'un Yeniden İnşası Bilad-ı Selase: Galata, Eyüp, Üsküdar, Türkiye İş Bankası Kültür Yayınları.

İnat, K. Ali Balcı (2010) "Makedonya: Balkanlar'da Tarihi Miras Kavgası ve Etnik Çatışma”, (Kemal İnat, B. Duran, Muhittin Ataman Ed.), Dünya Çatışmaları: Çatışma Bölgeleri ve Konularl, (3.Bask1), Nobel Yayınları 271-282.

Kamil, İ. (2017). "Krallık Döneminde Bulgaristan”, Balkanlar El Kitabı 2.Cilt: Çă̆daş Balkanlar, (Bilgehan A. Gökdağ- Osman Karatay, Ed), (3. Baskı), Akçă̆ Yayınları, 547-557.

Karpat, K. (1999). Etnik Kimlik ve Ulus-Devletlerin Oluşumu, (Güler Eren Ed.), Osmanl, Yeni Türkiye Yayınları, C.2,

Karpat, K (2004). Balkanlar'da Osmanlı Mirası ve Ulusçuluk, (1.Bask1), İmge Kitabevi.

Kedourie, E. (1970). Nationalism in Asia and Afrika, Cleveland:The World Pup Company.

Küçük, C (1999). İslam Hukukunda Gayrimüslimler, (Güler Eren Ed), Osmanll, Ankara Yeni Türkiye Yayınları, C. 4, 208-216.

Lütem, Ö. E. (2000). Türk-Bulgar İlişkileri 1983-1989, Avrasya Stratejik Araştırmalar Merkezi Yayınları.

Mansel, A. M. (2004). Ege ve Yunan Tarihi, Türk Tarih Kurumu Yayınları. 
Mazower, M. (2014). Bizans'ın Çöküşünden Günümüze Balkanlar, (Çev: Ayşe Ozil), Alfa Yayınları.

Okur, M. (2012). The Times Gazetesine Göre Makedonya Sorunu (1918-1945), Karadeniz Araştırmaları Dergisi, (32), 183-197.

Ortaylı, İ. (1985). Balkanlar'da Milliyetçilik, Tanzimat'tan Cumhuriyet'e Türkiye Ansiklopedisi, İstanbul, C.4,

Ortaylı, İ. (2012). Yakın Tarihin Gerçekleri, Timaş Yayınları.

Özcoşar, İ. (2003). Osmanlı Devleti’nde Gayrimüslimlerin Hukuki Durumu ve Millet Sistemi, Dicle Üniversitesi Hukuk Fakültesi Dergisi, 7(7), 124-139.

Renan, E. (1946). Millet Nedir?, Nutuklar ve Konferanslar (Discours et Counférences), (Çev: Ziya Ishan), Sakarya Basımevi.

Saatçi, M. B. (2002) Osmanlı İmparatorluğu'nun Son Döneminde Makedonya Sorunu, (M. Hatipoğlu Ed), Dünden Bugüne Makedonya Sorunu, Avrasya Stratejik Araștırmalar Merkezi Yayınları, 45-70.

Sadoğlu, H. (2016), Balkanlar'da Milliyetçilik ve Din, Internaional Journal of Political Studies, 2(1), 1-10. https://doi.org/10.25272/j.2149-8539.2016.2.1.01

Sannav, S. C. - Uğur Sezer (2018). Osmanlı Yönetim Sisteminin Rum İsyanına Etkileri, 2. Uluslararası Sosyal Bilimler Kongresi, 23-25 Mart 2018 Kudüs, Son Çağ Yayınları, 158175.

Saylak, S. A. (2016) Osmanl1-Rus İlişkilerinde Makedonya Sorunu (1885-1908), Gazi Akademik Bakıs Dergisi, 10(19), 107-134. https://doi.org/10.19060/gav.321005.

Smith, A. D. (1994). Milli Kimlik, (çev: Bahadır Sina Şener) (1.Baskı), İletişim Yayınları.

Smith, A. D. (2000). The Sacred Dimension of Nationalism, Millenium: Journal of International Studies, 29(3), 791-814. https://doi.org/10.1177/03058298000290030301

Sofuoğlu, E. -İlke Nur Akvarup, (2012). Osmanlı Devleti'nde Millet Sistemi ve Süryaniler, Akademik Incelemeler Dergisi, 7(1), 71-88.

Şener, B. (2014). Küreselleşme Sürecinde Ulus-Devlet ve Egemenlik Olguları, Tarih Okulu Dergisi, 7(18),51-77. http://dx.doi.org/10.14225/Joh500

Uludağ, M. B. - Soner Karagül, (2015). Ulus Devletten Avrupa ile Bütünleşmeye Romanya ve Bulgaristan'ın Siyasal Dönüşümleri, Rumeli Balkanlar Özel Sayısl-3 Yeni Türkiye, (68), 3016-3032.

Uzer, T. (1999). Makedonya Eşkiyalık Tarihi ve Son Osmanlı Yönetimi, Türk Tarih Kurumu Basimevi.

Yalçıner, R. (2014). Etnisite ve Milliyetçilik: Eleştirel bir Değerlendirme, Ankara Üniversitesi SBF Dergisi, 69(1),189-215. https://doi.org/10.1501/SBFder_0000002308

Yalçınkaya, M. A. (2017). Osmanlı Döneminde Bulgaristan, (Bilgehan A. Gökdağ- Osman Karatay Ed), Balkanlar El Kitabı 1.Cilt: Tarih, (3. Baskı), Akçă̆ Yayınları, 317-326.

Yerasimos, S. (1994) Milliyetler ve Sinırlar (Balkanlar, Kafkasya ve Orta-Doğu), (Çev. Şirin Tekeli), İletişim Yayınları.

Yetim, F. (2011). Osmanlı İmparatorluğu'nun Dağılma Döneminde Balkan Milliyetçiliği ve Büyük Göçler, Selçuk Üniversitesi Sosyal Bilimler Enstitüsü Dergisi, 25, 285-296. 